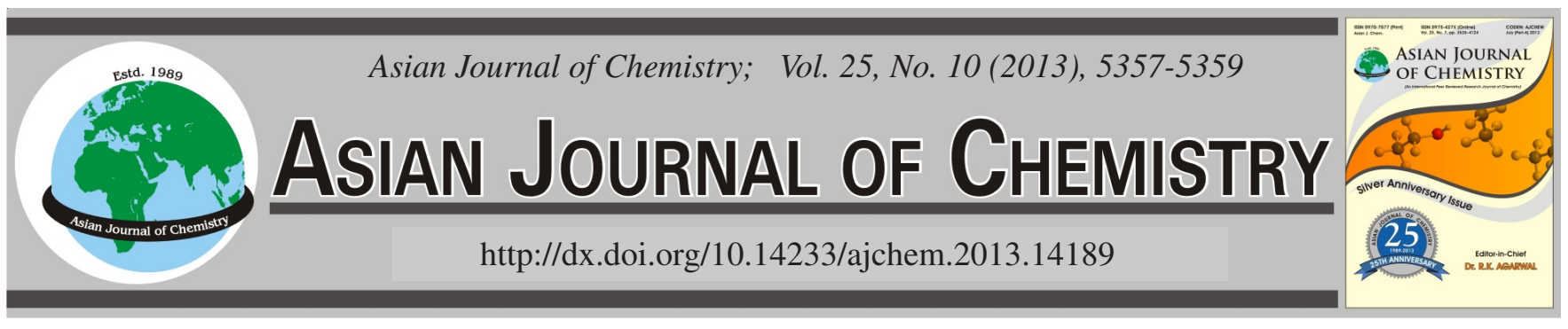

\title{
Phytoextraction of Chromium from Contaminated Soil by Brassica juncea as Influenced by Chelating Agents
}

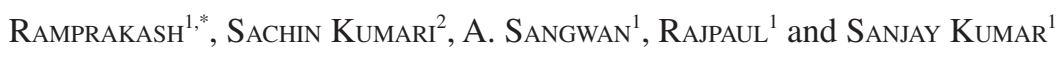

${ }^{1}$ Department of Soil Science, Chaudhary Charan Singh Haryana Agricultural University, Hisar-125 004, India

${ }^{2}$ Department of Chemistry, Chaudhary Charan Singh Haryana Agricultural University, Hisar-125 004, India

*Corresponding author: E-mail: ramsansanwal@gmail.com

(Received: 9 June 2012;

Accepted: 5 April 2013)

AJC-13204

\begin{abstract}
A pot experiment was conducted to evaluate the effect of amendments on phytoextraction of chromium using cyclohexanediaminotetraacetic acid, citric acid, diethylenetriamine-pentaacetic acid, nitrilotriacetic acid (at $3 \mathrm{mmol} \mathrm{kg}^{-1}$ soil) and farmyard manure (at $3 \%$ ) with Brassica juncea in the sewage sludge unamended and amended (at $3 \%$ ) soil. Application of chelating agents influenced dry matter yield and uptake of chromium by roots and shoots differentially depending upon the nature of the chelating agents. Dry matter yield of roots and shoots of Brassica juncea increased due to application of nitrilotriacetic acid, citric acid and farmyard manure whereas reverse trend was observed in cyclohexanediaminotetraacetic acid and diethylenetriamine-pentaacetic acid treated soils. Addition of sewage sludge at $3 \%$ on dry weight basis was found beneficial in improving the plant growth. Chelating agents enhanced the chromium uptake by both roots and shoots and significantly higher values of chromiumuptake by roots and shoots were observed from amended as compared to sewage sludge unamended soil. Application of nitrilotriacetic acid was found more effective in enhancing the chromium uptake by Brassica juncea roots and shoots than any other chelating agents at both the growth stages. The chelating agents are found useful in enhancing phytoextractability of chromium by Brassica juncea. Hence, marginally chromium contaminated soil may be remediated by adding chelating agents.
\end{abstract}

Key Words: Phytoextraction, Chromium, Chelating agents, Brassica juncea.

\section{INTRODUCTION}

Agricultural land contaminated with heavy metals is increased due to industrilization, urbanization and various anthropogenic activities such as use of treated and untreated waste water, sewage sludge, organic manure and compost and excessive use of fertilizer and pesticides is resulting into continuous production of huge amounts of heavy metals, which on reaching the agricultural fields get accumulated in soil at hazardous levels. Phytoremediation of heavy metal contaminated soils is an approach with a motive to extract excessive metals from marginally heavy metal contaminated soils through plant uptake. Amongst the commercial crops grown in this region Brassica juncea has been reported to produce high biomass and accumulate significant amount of heavy metals in their tissues when induced through the addition of chelating agents ${ }^{1}$. Use of sewage sludge and farmyard manure as source of organic matter is a common practice. However, use of sewage sludge continuously may increase heavy metals in soil but organic matter, present in the sludge can complex/ immobilize chromium and decrease their bioavailability ${ }^{2}$. Addition of chelating agents have been reported to increase heavy metal contents in the solution phase $\mathrm{e}^{3}$. Hence, higher extractability of chromium due to chelating agents may lead to their excessive accumulation in plants.

\section{EXPERIMENTAL}

The screen house experiment was conducted at CCS Haryana Agricultural University, Hisar, Haryana, India. For this the bulk surface sample $(0-15 \mathrm{~cm})$ of a sandy loam soil was collected from the experimental area of the dry land agriculture, CCS Haryana Agricultural University, Hisar, India. The soil sample taken was air dried, ground to pass through a $2 \mathrm{~mm}$ sieve and mixed thoroughly. The processed soil sample was used for laboratory and screen house studies. The bulk sewage sludge sample was collected from the Sewer Treatment Plant, Industrial Estate, Okhala, New Delhi. The bulk sample of well decomposed farmyard manure (FYM) was taken from the manure pit of dairy farm, CCS Haryana Agricultural University, Hisar, India. The physico-chemical properties of soil, sewage sludge and farmyard manure used are given in (Table-1). A screen house experiment was conducted to study the effect of chelating agents on phytoextraction of $\mathrm{Cr}$ by Brassica juncea from contaminated soils. Two soil treatments, 
viz., $\mathrm{Cr}$ spiked at $20 \mathrm{mg} \mathrm{Cr} \mathrm{kg}^{-1}$ soil and $\mathrm{Cr}$ spiked (at $667 \mathrm{mg}$ $\mathrm{Cr} \mathrm{kg}^{-1}$ sludge) sewage sludge added at $3 \%$ on dry weight basis, six chelating agents, viz. control $\left(\mathrm{Cr}_{20}\right)$, nitrilotriacetic acid (NTA), diethylenetriamine-pentaacetic acid (DTPA), cyclohexanediaminotetraacetic acid (CDTA), citric acid (CA) and farmyard manure were used. The $\mathrm{Cr}$ treated soil was filled separately in 72 polyethylene lined earthen pots ( 25 inch diameter) each at $5 \mathrm{~kg}$ soil pot $^{-1}$. A basal dose of $\mathrm{N}, \mathrm{P}, \mathrm{K}, \mathrm{Mn}$, $\mathrm{Fe}, \mathrm{Zn}$ and $\mathrm{Cu}$ at 50, 50, 60, 10, 10, 5 and $5 \mathrm{mg} \mathrm{kg}^{-1}$ soil was applied in solution form in each pot through their analytical grade salts. After addition of nutrient solutions, pots were wetted with deionized water to field capacity moisture content and kept for equilibration for one week and dried to workable moisture content. The contents of each pot were then taken out, mixed thoroughly, refilled and incubated for ten days at near field capacity moisture content and process of mixing was repeated again. Soil samples were drawn from each pot before sowing. Ten healthy seeds of the Brassica juncea cultivar were sown in each pot. After emergence of seedlings, only four plants per pot were allowed to grow. Second dose of nitrogen was applied at $25 \mathrm{mg} \mathrm{N} \mathrm{kg}^{-1}$ soil in solution form 30 days after sowing. The pots were irrigated with deionized water as and when required. Chelating agents were applied $\mathrm{at}^{3} \mathrm{mmol}$ $\mathrm{kg}^{-1}$ soil (1 mmol daily for 3 days in 3 split doses) 40 days after sowing. Ten days after application of chelating agents half of the mustard crop (i.e. 3 replication out of 6) were harvested and remaining 3 replications of each treatment where harvested after 80 days after sowing. In order to determine $\mathrm{Cr}$ in root and shoot sample, wet digestion was carried out in a diacid mixture of nitric acid and perchloric acid in 4:1 ratio. Chromium in the digest was determined by using atomic absorption spectrophotometer (GBC-932 plus). Stastistcal analysis were done using factorial completely randomized design.

\begin{tabular}{|c|c|c|c|}
\hline \multicolumn{4}{|c|}{$\begin{array}{c}\text { TABLE-1 } \\
\text { PHYSICO-CHEMICAL CHARACTERISTICS OF THE } \\
\text { EXPERIMENTAL SOIL, SEWAGE SLUDGE } \\
\text { AND FARM YARD MANNURE (FYM) }\end{array}$} \\
\hline \multirow{2}{*}{ Properties } & \multicolumn{3}{|c|}{ Content } \\
\hline & Soil & Sewage sludge & FYM \\
\hline $\begin{array}{l}\text { Mechanical composition } \\
\text { (a) Sand (\%) }\end{array}$ & & & \\
\hline (b) Silt $(\%)$ & 16.50 & - & - \\
\hline (c) Clay (\%) & 13.80 & - & - \\
\hline Textural class Sandy loam & & - & - \\
\hline $\mathrm{pH}(1: 2)$ & 8.10 & 7.20 & - \\
\hline $\mathrm{EC}_{1: 2}\left(\mathrm{dS} \mathrm{m} \mathrm{m}^{-1}\right)$ & 0.50 & 2.10 & - \\
\hline Organic carbon $(\%)$ & 0.32 & 12.20 & 27.80 \\
\hline $\mathrm{CEC}\left[\mathrm{Cmol}\left(\mathrm{P}^{+}\right) \mathrm{kg}^{-1}\right]$ & 11.80 & - & - \\
\hline $\mathrm{CaCO}_{3}(\%)$ & 0.40 & 0.25 & - \\
\hline \multicolumn{4}{|l|}{ Total Nutrients (\%) } \\
\hline (a) Nitrogen & 0.09 & 1.29 & 1.18 \\
\hline (b) Phosphorus & 0.01 & 0.41 & 0.70 \\
\hline (c) Potassium & 0.10 & 0.73 & 2.50 \\
\hline \multicolumn{4}{|l|}{ Total metals $\left(\mathrm{mg} \mathrm{kg}^{-1}\right)$} \\
\hline $\mathrm{Cr}$ & 0.12 & 7.2 & \\
\hline $\mathrm{Pb}$ & 0.98 & 64.2 & \\
\hline
\end{tabular}

\section{RESULTS AND DISCUSSION}

Dry matter yield of roots and shoots: Dry matter yield of roots and shoots of Brassica juncea is influenced differentially by chelating agents (Table-2). The mean dry matter yield of roots of Brassica juncea was 1.08, $1.34 \mu \mathrm{g} \mathrm{pot}^{-1}$ diethylenetriaminepentaacetic acid, cyclohexanediaminotetra acetic acid only as compared to $1.64,2.25,2.33$ and $2.82 \mu$ got $^{-1}$ in, $\mathrm{Cr}_{20}$, farmyard manure, citric acid and nitrilotriacetic acid applied plants. Nitrilotriacetic acid and citric acid significantly improved the root biomass than diethylenetriamine-pentaacetic acid and cyclohexanediaminotetraacetic acid. Application of nitrilotriacetic acid increased the dry matter of Brassica juncea roots by 114.11 at first stage and $76.03 \%$ at second stage of growth in sewage sludge untreated soil, respectively as compared to control. Similar results were also observed at second growth stage. Per cent increase in shoot biomass due to nitrilotriacetic acid was $295.25 \%$ at first and $238.16 \%$ at second stage of growth in sewage sludge unamended soil, respectively but the relative increase was much less at second stage in comparison to control. However, addition of cyclohexanediaminotetra acetic acid and diethylenetri-amine-pentaacetic acid reduced the same probably due to increased extractability of $\mathrm{Cr}$ and other heavy metals in the rhizosphere which in turn might have caused higher reduction in growth ${ }^{4,5}$.

\section{TABLE-2}

EFFECT OF CHELATING AGENTS AND SEWAGE SLUDGE ON DRY MATTER YIELD $\left(\mathrm{g} \mathrm{pot}^{-1}\right)$ OF ROOTS AND SHOOTS OF Brassica juncea CROP IN Cr CONTAMINATED SOIL

\begin{tabular}{|c|c|c|c|c|c|}
\hline \multicolumn{3}{|c|}{50 DAS } & \multicolumn{3}{|c|}{80 DAS } \\
\hline Treatment & $\begin{array}{l}\text { Without } \\
\text { SS }\end{array}$ & $\begin{array}{c}\text { With } \\
\text { SS }\end{array}$ & $\begin{array}{l}\text { Without } \\
\text { SS }\end{array}$ & $\begin{array}{l}\text { With } \\
\text { SS }\end{array}$ & Mean \\
\hline \multicolumn{6}{|c|}{ Root } \\
\hline $\mathrm{Cr}_{20}$ & 0.85 & 1.21 & 2.10 & 2.41 & 1.64 \\
\hline $\mathrm{Cr}_{20}+\mathrm{CDTA}$ & 0.79 & 1.00 & 1.61 & 1.95 & 1.34 \\
\hline $\mathrm{Cr}_{20}+\mathrm{CA}$ & 1.67 & 2.11 & 2.65 & 2.91 & 2.33 \\
\hline $\mathrm{Cr}_{20}+\mathrm{DTPA}$ & 0.71 & 0.90 & 1.26 & 1.45 & 1.08 \\
\hline $\mathrm{Cr}_{20}+\mathrm{NTA}$ & 1.82 & 2.13 & 3.56 & 3.78 & 2.82 \\
\hline $\mathrm{Cr}_{20}+\mathrm{FYM}$ & 1.65 & 1.96 & 2.51 & 2.88 & 2.25 \\
\hline Mean & 1.25 & 1.55 & 2.28 & 2.56 & \\
\hline $\mathrm{CD}(0.05)$ & \multicolumn{5}{|c|}{$\begin{array}{l}\text { Soil }=0.07 ; \text { Time }=0.07 ; \text { Chelating agent }=\text { NS; SxT } \\
=0.11 ; \text { SxCA }=0.19 ; \text { TxCA }=\text { NS; SxTxCA }=\text { NS }\end{array}$} \\
\hline \multicolumn{6}{|c|}{ Shoot } \\
\hline $\mathrm{Cr}_{20}$ & 2.53 & 4.14 & 14.58 & 16.16 & 9.35 \\
\hline $\mathrm{Cr}_{20}+\mathrm{CDTA}$ & 2.43 & 3.98 & 13.18 & 15.89 & 8.87 \\
\hline $\mathrm{Cr}_{20}+\mathrm{CA}$ & 8.54 & 12.11 & 18.46 & 20.00 & 14.78 \\
\hline $\mathrm{Cr}_{20}+$ DTPA & 1.93 & 2.87 & 12.51 & 14.64 & 7.99 \\
\hline $\mathrm{Cr}_{20}+\mathrm{NTA}$ & 10.00 & 14.00 & 22.41 & 23.65 & 17.51 \\
\hline $\mathrm{Cr}_{20}+\mathrm{FYM}$ & 7.58 & 9.56 & 16.11 & 19.11 & 13.09 \\
\hline Mean & 5.50 & 7.78 & 16.21 & 18.24 & \\
\hline $\mathrm{CD}(0.05)$ & \multicolumn{5}{|c|}{$\begin{array}{l}\text { Soil }=0.54 ; \text { Time }=0.54 ; \text { Chelating agent }=\text { NS; SxT } \\
=0.76 ; \text { SxCA }=1.31 ; \text { TxCA }=\text { NS; SxTxCA }=\text { NS }\end{array}$} \\
\hline
\end{tabular}

Chromium uptake by roots and shoots: Application of chelating agents significantly increased uptake $\mathrm{Cr}$ by Brassica juncea roots as compared to control $\left(\mathrm{Cr}_{20}\right)$ at both the growth stages (Table-3). The per cent increased in uptake of $\mathrm{Cr}$ by roots due to nitrilotriacetic acid treatment was $137.63 \%$ as compare to control $\left(\mathrm{Cr}_{20}\right)$ alone. The mean uptake of $\mathrm{Cr}$ by root increased from 67.87 to $89.47 \mu$ pot $^{-1}$ due to increasing sewage sludge level from 0 to $3 \%$ at first stage of growth. The relative increasing being much higher at second stage of growth, respectively. Application of nitrilotriacetic acid was found more effective in improving $\mathrm{Cr}$ uptake by roots than any other chelating agents. The data in Table- 3 further reveal 


\begin{tabular}{|c|c|c|c|c|c|}
\hline \multicolumn{6}{|c|}{$\begin{array}{l}\text { EFFECT OF CHELATING AGENTS AND SEWAGE SLUDGE ON } \\
\text { Cr UPTAKE }\left(\mu \mathrm{g} \mathrm{pot}^{-1}\right) \text { BY ROOTS AND SHOOTS OF SUBSE- } \\
\text { QUENT Brassica juncea CROP IN Cr CONTAMINATED SOIL }\end{array}$} \\
\hline \multicolumn{3}{|c|}{50 DAS } & \multicolumn{3}{|c|}{80 DAS } \\
\hline Treatment & $\begin{array}{l}\text { Without } \\
\text { SS }\end{array}$ & $\begin{array}{l}\text { With } \\
\text { SS }\end{array}$ & $\begin{array}{l}\text { Without } \\
\text { SS }\end{array}$ & With SS & Mean \\
\hline \multicolumn{6}{|c|}{ Root } \\
\hline $\mathrm{Cr}_{20}$ & 34.31 & 53.91 & 128.52 & 154.43 & 92.79 \\
\hline $\mathrm{Cr}_{20}+\mathrm{CDTA}$ & 41.17 & 56.26 & 108.92 & 136.69 & 85.76 \\
\hline $\mathrm{Cr}_{20}+\mathrm{CA}$ & 98.68 & 133.81 & 201.84 & 232.73 & 166.77 \\
\hline $\mathrm{Cr}_{20}+\mathrm{DTPA}$ & 34.46 & 48.28 & 82.14 & 100.06 & 66.23 \\
\hline $\mathrm{Cr}_{20}+\mathrm{NTA}$ & 125.72 & 151.55 & 288.49 & 318.95 & 221.18 \\
\hline $\mathrm{Cr}_{20}+\mathrm{FYM}$ & 72.87 & 92.99 & 161.19 & 194.57 & 130.41 \\
\hline Mean & 67.87 & 89.47 & 161.85 & 189.57 & \\
\hline $\mathrm{CD}(0.05)$ & $\begin{array}{l}\text { Soil }=6.9 \\
=9.84 ; \mathrm{S}\end{array}$ & $\begin{array}{l}\text { Time }=0 \\
\mathrm{~A}=17.0\end{array}$ & $\begin{array}{l}\text { 96; Chelat } \\
\text {;xCA = }\end{array}$ & $\begin{array}{l}\text { hg agent }= \\
\text { VS; SxTxC }\end{array}$ & $\begin{array}{l}\mathrm{IS} ; \mathrm{SxT} \\
=\mathrm{NS}\end{array}$ \\
\hline \\
\hline $\mathrm{Cr}_{20}$ & 51.59 & 124.61 & 469.35 & 567.46 & 303.25 \\
\hline $\mathrm{Cr}_{20}+\mathrm{CDTA}$ & 85.40 & 154.07 & 560.01 & 758.78 & 389.57 \\
\hline $\mathrm{Cr}_{20}+\mathrm{CA}$ & 335.41 & 530.77 & 881.29 & 1039.33 & 696.17 \\
\hline $\mathrm{Cr}_{20}+$ DTPA & 59.36 & 99.43 & 453.53 & 581.73 & 298.51 \\
\hline $\mathrm{Cr}_{20}+\mathrm{NTA}$ & 411.44 & 646.53 & 1125.69 & 1289.10 & 868.19 \\
\hline $\mathrm{Cr}_{20}+\mathrm{FYM}$ & 194.26 & 273.84 & 547.09 & 694.54 & 427.43 \\
\hline Mean & 189.57 & 304.88 & 672.83 & 821.82 & \\
\hline $\mathrm{CD}(0.05)$ & \multicolumn{5}{|c|}{$\begin{array}{l}\text { Soil }=38.7 ; \text { Time }=38.7 ; \text { Chelating agent }=\text { NS } \text { SxT } \\
=54.73 ; \text { SxCA = 94.8; TxCA = NS; SxTxCA = NS }\end{array}$} \\
\hline
\end{tabular}

that mean uptake of $\mathrm{Cr}$ by shoot increased from $303.25 \mu \mathrm{g}$ pot $^{-1}$ in control $\left(\mathrm{Cr}_{20}\right)$ to $389.57,696.17,868.19$ and 427.43 $\mu \mathrm{g}$ pot $^{-1}$ due to application of cyclohexanediaminotetraacetic acid, citric acid, nitrilotriacetic acid and farmyard manure in the shoot of Brassica juncea, respectively. The mean Cr uptake by shoots of Brassica juncea plants increased from 189.57 to $304.88 \mu$ pot $^{-1}$ due to increasing sewage sludge level from 0 to $3 \%$ at first stage of growth and from 672.83 to $821.82 \mu \mathrm{g}$ pot $^{-1}$ at second stage of growth, respectively. Application of nitrilotriacetic acid increased the Cr uptake by Brassica juncea shoot by 692.30 and $417.2 \%$ in sewage sludge unamended and amended soils at first stage of growth. Among the chelating agents, nitrilotriacetic acid caused significant increase in $\mathrm{Cr}$ uptake in comparison to other chelating agents. Sewage sludge application resulted in increased uptake of $\mathrm{Cr}$ by roots and shoots of Brassica juncea. The increased uptake of Cr by Brassica juncea might have been due to increased availability of $\mathrm{Cr}$ in soils due to addation of chelating agentsresulting in its higher accumulation in roots and and shoots and higher dry matter yields of both the components of Brassica juncea ${ }^{6,7}$.

\section{REFERENCES}

1. M.J. Blaylock, D.E. Salt, S. Dushenkov, O. Zakharova, C. Gussman, Y. Kapulnik, B.D. Ensley and I. Raskin, Environ. Sci. Technol., 31, 860 (1997).

2. M.B. McBride, C.E. Murtinez and S. Sauve, Soil Sci. Soc. Am. J., 62, 1542 (1998).

3. C.W. Gray, R.G. Mclaren, A.H.C. Roberts and L.M. Condron, Aust. J. Soil Res., 37, 461 (1999).

4. B.H. Robinson, T.M. Mills, D. Petit, L.E. Fung, S.R. Green and B.E Clothier, Plant and Soil, 227, 301 (2000).

5. H. Greman, D. Vodnik, S. Velikonja-Bolta and D. Lestain, J. Environ. Qual., 32, 500 (2003).

6. S. Ishikawa, A.E. Noriharu, M.I. Masaharu and W. Tadao, Soil Sci. Plant Nut., 52, 32 (2006).

7. B. Kos, H. Greman and D. Lestan, Plant Soil Environ., 49, 548 (2003). 